\title{
Dogs and humans and what earth can be
}

\section{Filaments of Muslim ecological thought}

\author{
Naveeda KHAN, Johns Hopkins University
}

Climate change is knowledge produced by running empirical data on weather through global simulation models. In contradistinction to the approach that studies how people come to be schooled to perceive climate change or produce their own accounts of change in an indigenous idiom, I show how knowledge of it is met by disbelief by Muslim farmers (chauras) living on eroding and accreting silt and sand islands (chars) within the Jamuna River in Bangladesh. Such disbelief is not unlike the denial that ordinarily greets news of climate change elsewhere. If one were to turn away from asking how people are taking up (or not) the issue of climate change, it is in smaller gestures of incorporating repugnant others, in this case dogs, that one sees reflections on divine creation qua creatureliness. And following such reflections on Creation through fables, narratives, and the everyday of the chauras, we see how Muslim cosmology and eschatology hold promise of ecological thought, providing an unexpectedly materialist perspective on our creaturely interconnectedness. They also provide an anticipatory register of climate change within chaura life through the intensification of suffering in the present, while allowing for disbelief in climate change as poisoned knowledge from the West.

Keywords: climate change denialism, Muslim cosmology and eschatology, dog-human relations, Bangladesh

\section{Creation as ecological thought}

On a summer's night in 2011 in the market place of a village located on an island of silt and sand (char) that accretes and erodes within the Jamuna River in Bangladesh, I was asked to replay the research directive that had brought me to this village for the past two years. By this time I was thoroughly disabused of the notion that "the indigenous" expound intrinsic knowledge about climate change. 
I half-heartedly mumbled jol bayu poriborton, the Bangla term for climate change in national discourses. The villagers at the tea stall where we were downing cups of sweet tea in the deep darkness distinctive of char nights were all men of a certain age and stature. They laughingly pulled out Porosh, the half-blind disabled man, who was considered the village fool, with the words, "He'll answer all your questions." Porosh, proud to be brought forward, launched into a mini lecture in formal Bangla on climate change reproduced almost word for word out of any number of posters and pamphlets regularly distributed by the NGOs in the area. As he expounded on flash floods, the erraticism of agricultural seasons, the increase in destructive insects, and the growing unseasonality of illness, the men howled with laughter.

I was aghast at the cruelty displayed toward Porosh and the blindness of the men to their plight because the litany of natural horrors that Porosh recited was already evident in the char. However, on further reflection, I realized that it was I who ought to question the certainty with which I alighted on climate change as the reason for the growing uncertainties and suffering in these parts. Although I am not a skeptic of climate science, I sensed that it took more than expert knowledge and guidance to make the leap from weather to climate, as Paul N. Edwards (2010) claims. While empirical data run through models may produce scientific knowledge of climate change, it also took a leap of faith to cross scales, to have a feeling for change. Even then we may not arrive at a picture of climate change as effects of human activity upon the world, as the science would like us to. Thus who is to say that the event I recount above is either a denial of climate change supposedly born of ignorance, or a gesture of ludic transcendence of a present whose changing contours were otherwise all too well known. Consequently, the question of climate change for me is not how a distinct people in a specific locale experience it, but rather how, in experiencing it, climate change is met by a kind of disbelief not unlike the tenor of denial that ordinarily greets it within lives elsewhere (Norgaard 2011) but that still leaves open the possibility of other modes of anticipating it (Khan 2014).

In The ecological thought (2010), Tim Morton maintains that it is our obdurate hold upon a picture of the world as pristine nature being destroyed by humans which prevents us from having an ecological thought, that is, a perspective on our interconnectedness and mutual entanglements. Similarly, disappointed with the promise of climate science in effecting a meaningful engagement with the world and our place within it, Bruno Latour (2009) asks if theology, in his case Christian theology, may not offer us a way toward sensing our embeddedness in this world. Latour puts forward "Creation" as the means to renew our sense of cohabiting the world with others by forcing us to consider if all of God's creations are to receive salvation.

What the two theorists give us most significantly is an image of thought that is not interiorized and introspective but emergent within a milieu and interconnecting across time and space. ${ }^{1}$ And what Latour gives us specifically is Creation as a

1. This notion of thought as immanent in the world has a long anthropological genealogy. For instance, foremost among Lévi-Strauss' insights is that thought is always in the world. In one of his many eloquent descriptions of thought in Tristes tropiques, we are told of how being in the world subsumes realms of both abstractness and concreteness: 
potent thought generative of interconnections across species. This raises the question for me: Might Creation be similarly generative of interconnections between humans and other animals within the Muslim context predominant in the chars? In this paper I first recount an event from my fieldwork in which my clumsy efforts involving a troublesome dog led to the vehement assertion of the creaturely status of dogs by my chaura interlocutors. I had been intrigued by the insistent presence of dogs in the char landscape and in narratives despite the visceral disgust in which they were held (not unlike other Muslim societies; see Roff 1983). However, this new assertion of a possible kinship between humans and dogs led me to look again at my material, to realize how Creation narratives provided the filaments of Muslim ecological thought as a perspective on our interconnectedness and mutual entanglements. And it was such reflections on Creation and the attendant cosmology and eschatology that inadvertently introduced an anticipatory register of climate change within everyday life in the chars, while allowing for disbelief in climate change as knowledge produced elsewhere.

\section{Dogs as God's creation}

January 2012 found me in a very difficult situation. I was on my ninth month of living in a village on the char. I had a room of my own at the end of a row of rooms that housed offices and flop beds for those working at the NGO that was hosting me. During the day, I would step into the courtyard filled with employees of the $\mathrm{NGO}$, those come to procure loans, children and passersby stopping by to see what was going on, and dogs. Mangy, moth-eaten dogs lolled about, their lethargic states an indication of their states of starvation. Sometimes they would prick their ears and jump up ready to bark or battle other dogs passing by. And sometimes, particularly in these cool winter days, they would vigorously copulate, to the amusement of the people sitting around. Then, of course, there would be puppies.

At nighttime the scenario was different. I would step out of the dark of my room into the darkness outside. While I could see quite a ways ahead with my US-bought torch, the inky darkness bled in from the sides. Most crucially, I couldn't always see what animals I was going to come upon. While most farm animals (horses, cows, sheep, goats, geese, ducks, chickens) would be huddled in the scanty rooms of their owners by nightfall, the sudden appearances of frogs or cats would startle me. But it was dogs I was afraid of stumbling upon. There was one in particular that had taken to living with her litter on the compound.

This dog had already bitten a few people, undoubtedly to defend her young, but it was unclear what action would trigger her offensive and I was afraid lest my nighttime walking aroused her suspicions. It was commonly known in these parts that one

\footnotetext{
"I owe myself to mankind, just as much as to knowledge. History, politics, the social and economic universe, the physical world, even the sky-all surround me in concentric circles, and I can only escape from those circles in thought if I concede to each of them some part of my being. Like the pebble which marks the surface of the wave with circles as it passes through it, I must throw myself into the water if I am to plumb the depths" (Lévi-Strauss 1961: 396).
} 
became pregnant when bitten by dogs, and as the pregnancy was not to be on account of being interspecies, the bitten person descended to madness before dying a horrible death. This seemed an apt description for rabies, of which most dogs in Bangladesh were possible carriers. ${ }^{2}$ I was afraid of being bitten. I wanted the dog "dealt with."

The villagers discussed whether the dog should be put down or not, but no one did anything about it. I offered incentives. This started a peculiar showmanship in which people would band together to chase the dog with a stick, but would invariably fail to kill her. Instead they would return to my room to be rewarded with sweetmeats for trying. Then they decided to do something with the litter, the dog's obvious point of attention. While no one would actually kill the litter, they took the little puppies to different parts of the village to leave them there to be taken by kites or foxes-except the dog brought them back and finally moved them underneath the verandah attached to my room. People marveled at her canniness in bringing her babies and seeking the protection of the very person who sought her destruction.

I began to feel queasy at my participation in this hunt and asked to call it off. However, the dog had become more defensive and lunged at anyone who stepped foot on the compound. Although I had withdrawn my assent to killing the dog, the word was out that I had to have it dead. Borkot and Shopon, my two young friends who loved to do little things for me, as much to avoid going to school as to endear themselves to me, once found the puppies unprotected by their mother. They took the pups far away, where they were undoubtedly food for other animals or at the mercy of the teasing of children. The two happily skipped back to report what they had done to me while I groaned inwardly.

The furious discussions that resulted from my signature on this action led me to wonder what kind of minefield I had walked into. A person from an impromptu group gathered on the compound to discuss the event asked me testily, "Can we kill God's creatures (makhluqh) so easily?" When I pointed out the routine slaughter and sacrifice of chickens, pigeons, goats, and cows in the village and abroad, I was told that those had been given to us to eat and we did not kill them gratuitously.

After the event, the dog took to howling so sadly in the night that once, as I squatted over a fire with a friend cooking our evening meal, I found her face awash with tears, moved by the pathos of the dog's cries. We didn't speak any further about the dog, which continued to lop around the compound unfed and increasingly listless in her search for food, at least until the cow plague began shortly afterward. This was my most impassioned encounter with the language of Creation and creatureliness in the field.

\section{Creation in Muslim narratives}

Muslim narratives of Creation share with Christian ones the image of an omnipotent God who created the world, the cosmos, and the whole from nothing in a

2. A December 2012 dispatch from the Center for Disease Control and Prevention puts Bangladesh as having the world's third largest death rate for human rabies, an estimated 2,100 deaths out of 55,000 persons a year. Dogs are the primary carriers of the virus (http:// wwwnc.cdc.gov/eid/article/18/12/12-0061_article.htm, accessed December 18, 2014). 
grand act of spontaneous generation. He filled it with a diversity of his creations, ethereal, animate and inanimate, visible and invisible, each with its own distinctive capacity. And he placed them in the milieus most appropriate to them, suggesting an adaptive fit between body and surround. It is said he created humans last of all because he wanted to leave the most perfect creation to the end, but this also consigned humans to a state of belatedness to the world (Goodman 1978).

The Islamic view of the world is unapologetically anthropocentric, holding God in thrall with humans, and making the human drama the most important one to watch (Manzoor 2003). Even rocks, trees, and wild animals, for instance, bear witness to the call to prayer and the subsequent prayer of the solitary traveler traveling in their midst. But the fact that they can do so suggests that they have an acknowledged existence as both God's creation and agents in the world. And their testimony carries weight in the court of God.

The nonhuman also has an independent claim to worship insofar as humans are told that when they pray alone in the deepest woods, they pray alongside nature. The prayer of nature consists in doing what it has been created to do. Both the regularity in nature and being true to one's own nature are acts of worship that bear witness to and continuously revivify God's creation (Murata and Chittick 1998). Consequently, although the textual tradition focuses on humans, elements within it suggest a larger side-story of animals and other beings whose existence appear mostly independent of humans.

Perhaps the most vividly imagined of such side-stories is the fable The case of the animals versus man before the King of the Jinn by the Ikhwan al-Safa (The Brethren of Purity), a secret society of Muslim thinkers thought to have been active in Basra, Iraq, in the tenth century. This fable is part of a larger encyclopedic work with pedagogic intent compiled by the Brotherhood that is widely disseminated and read within Muslim-majority societies (Nasr 1993). And through it continues a tradition of hermeticism within Islam. My focus on this fable, however, is not to trace the possible influence of this work upon the chars. That is a task beyond the scope of this paper. I point only to Khizr, the Prophet in Green, who is associated with hermeticism and also has a presence within the chars as a way to suggest a subterranean connection between this textual tradition and the everyday lives of riparian Muslims in Bangladesh. My interest in the fable is to draw out its meditation on the creaturely nature of animals in relation to humans, focusing on the specific relation between humans and dogs, before turning to the fable's resonance with chaura meditations on dogs.

In the main story of the fable, animals subjugated by humans approach the King of Jinns to ask his help in challenging human claims to superiority and right to dominate the animals. To mediate between the two groups, the King entertains extended arguments from all sides. The fable unfolds as a disputation between humans and animals. In his introduction to his translation of the fable, Lenn E. Goodman (1978) points out that the Ikhwan do not present the animals as symbolic representations of humans. They attempt to attend as exhaustively as possible to the animals' points of view, producing accounts somewhere between naturalistic and theological. Goodman claims that the Ikhwan grant animals "virtual subjecthood," such that if they could be subjects within a human framework, they would have discourse worthy of the most eloquent human. So, for instance, in the opening 
pages of the fable, a mule in the court of the King of Jinns bursts forth with an expressive and elemental account of Creation:

Praise be to God, One, Unique and Alone, Changeless, Ever-biding and Eternal, who was before all beings, beyond time and space and then said, "BE!" - at which there was a burst of light He made shine forth from His hidden Fastness. From this light He created a blazing fire and a surging sea of waves. From fire and water He created spheres studded with stars and constellations, and the blazing lamp of the heavens. He built the sky, made wide the earth and firm the mountains. He made the many storeyed [sic] heavens, dwelling place of the archangels; the spaces between the spheres, dwellings of the cherubim. The earth he gave to living things, animals, and plants. He created the jinn out of the fiery simoom and humans out of clay. He gave man posterity "from vile water in a vessel sure," allowed man's seed to succeed one another on earth, to inhabit it, not to lay it waste, to care for the animals and profit by them, but not to mistreat or to oppress. God grant pardon to you and to myself. (Ikhwan aql-Safa 1978: 54)

The mule continues on to say, "Your Majesty ... there is nothing in the verses the human has cited to substantiate his claims that they are masters and we slaves" (ibid.: 55). And in a damning condemnation of humans, he says, "They captured sheep, cows, horses, mules, and asses from among us and enslaved them, subjecting them to the exhausting toil and drudgery of hauling, being ridden, plowing, drawing water and turning mills" (ibid.).

While it would seem evident that the Ikhwan grant animals privileged access to being subjects in their own rights, I would argue that they could be read as doing something bolder. In the mule's ability to recount the Creation narrative in such detail, what the Ikhwan suggest is that every creature knows and speaks of Creation, that this knowledge is not the privilege of humans alone. Furthermore, it is the failure of humans to not hear this discourse of nature, to imagine that they live in the presence of mute nature when there is cacophony about them. The condemnation of humans is thoroughgoing, in keeping with the Ikhwan's philosophical commitment to truth telling to enable self-knowledge and spiritual striving (Nasr 1993).

In this heated exchange between animals and humans, three arguments are noteworthy that make human claims to superiority over other animals to be faulty in reasoning. Humans' claim that the perfection of their anatomy-that is, form, posture, gait, and senses - gives them superiority over animals is met with the words:

God did not create them in this form or shape them in this way to show that they are masters. Nor did He create us in the form we have to show that we are slaves. Rather He knew and wisely ordained that their form is better for them and ours for us.... Since He gave us the grass on the ground for our food, He made us face downward so it would be easy for us to reach it. (Ikhwan al-Safa 1978: 56-57)

Here shape is of divine endowment, best befitting one's milieu.

Just as one's shape is value-free, so is one's essential nature. For instance, humans view snakes as malevolent creatures as their poison delivers nothing but harm to humans. The snake rebuts this by stating that "had this poison not been created for snakes, there would be no food fit for them to eat. They would not be nourished 
and would die of starvation" (ibid.: 57). In other words, the snake's poison has been created for itself. And humans do wrong in misunderstanding that God's creatures have been birthed only in relation to humans.

To the humans' claim to have a superior mind, creativity, and the capacity to build lasting objects, we have Yasub, the prince of bees, who responds by saying, "Among our special gifts and blessings from our Lord are the skill and knowledge of the geometrical arts with which we are inspired and instructed by God and which we use in building our homes, constructing our dwellings, and gathering our stores" (ibid.: 138). The bees' body is presented as an architectural creation in its own right to enable it to make such creations. "For God in His wisdom gave me a most intricate and ingenious body and a wondrous form in that He gave me a body divided into three articulated parts. ... With these four legs and two hands, from the leaves of trees and the blossoms and succulent fruit, I gather the resinous fluids with which I build my dwellings and apartments" (ibid.).

Thus in all ways, save for one, animals are on par with humans and refuse to take them as their measure. Instead the animals insist that only divine creation should be the ground of all claims, with the fact of having been created by God assuring the salvation of all animals. This is a marked difference from the Christian context that Latour speaks of, in which the question of the salvation of animals is still an open one based on whether they have souls or not to be saved.

While I leave the conclusion of the fable for later in the paper, I want to point to the sudden burst of pathos for humans expressed by the animals in the midst of their otherwise outright condemnation of humanity. This outburst speaks to how dogs come to be associated with humans. The animals despair that in forgetting their divinely ordained nature and those of others, humans have lost the ability to form lasting relationships with other animals. While groups form and re-form in the animal kingdom through friendship, companionship, or even just mutual respect and acknowledgment of the relations of predation among them, humans have no real friends amongst animals. Some point to dogs and cats as animals that have given companionship to humans. Yet they too are presented as beasts lost to their own nature and divorced of the capacity to form genuine relations. So says the bear:

Dogs are drawn to the neighborhood and habitation of men simply because they are like them in nature and akin to them in character. With men they found the food and drink they relish and yearn for as well as a greedy, covetous, ignoble, and stingy nature like their own. The contemptible qualities which they found in men are all but unknown among carnivores. (Ikhwan al-Safa 1978: 87)

The history of this uncanny doubling between humans, and dogs and cats, is also found in the textual tradition by the animals:

When Cain killed his brother Abel, the sons of Abel sought to avenge their father. They made war upon the sons of Cain and they slaughtered one another. But the family of Cain defeated the family of Abel ... they began to give feasts and entertainments for which they slaughtered many animals. ... The dogs and cats, transported at the sight of such abundance and luxury, left their own kind and went over to man. They have remained the allies of man ever since. (Ikhwan al-Safa 1978: 89) 
Thus began the aberrant relationship between humans and dogs, which may have started with a shared creatureliness and companionship but entailed a turn to cofeasting on the flesh of the world.

This fabulatory understanding of human-dog relations finds its resonance within the chars. Dogs are somewhere on the spectrum between farm animals and wild animals. A few villagers feed leftover rice to dogs to ensure that the dogs protect their homestead from human and animal strangers. But this does not necessarily tie dogs to the homestead for perpetuity, for homesteads move with the accreting and eroding of land, people's commitment to providing food, protection, and passage waver, and dogs are drawn to others. One woman described in a tearful voice how one morning a dog that she had raised from its birth moved to another house and would now growl at her every time she went close to it. Another woman, overhearing her relate the story, hurrumphed and said, "What did you expect? It's a dog."

Not only did dogs turn away from dog society to become entrenched in human society, they continued to perpetuate their loyalty to humans at the expense of blood ties. "They can kill their own father," writes Nogendro Nath Basu in a special issue on "Doglore" of the Bangla journal Loksamaskriti Gabeshana (Research on Folk Culture) (1997: 134). On several occasions in the chars I heard people either marvel or express disgust at the fact that a dog of their acquaintance would attack even its own mother should she come close to the house to which the dog was associated. And these feelings of ambivalence, of both appreciating dogs' loyalty to humans and judging them for turning against their own kind, qualified the loyalty of dogs. Given that it had betrayed once, it was in its nature to betray. Yet, while there is much resonance between the tenth-century fable's representation of dogs and the present-day treatment of them in the chars, the first chaura woman's sadness over her lost dog nonetheless endured over the course of my time in the field and requires a different accounting.

\section{Mutual fated-ness}

"Be careful of dogs," said the widow whom we called Khala or aunt out of respect, and to whom belonged the dog which protected her largely female household. We were walking in the dark over gravel paths and open fields pocked by craters from which soil had been scooped up to raise households. This being a time before I discovered powerful torches, the weak light of my cell phone led us. It was another wintertime, January 2010, two years prior to the event with which I started the paper. It was already dawning on me that something about the winter not only served as a time favorable for holding public events, insofar as it was the dry season, it also lent itself to philosophizing on one's creaturely status. We were heading to a house in the cluster village immediately north of the one in which I was put up. There was to be an Islami shobha, a program of moral lectures. "Dogs?" I asked. "Yes, didn't you see the dogs fighting this morning?" returned Khala. I had seen the fight and was not a little scared by the ferocity with which they confronted one another. But what had caught my attention, as I stood on the NGO compound raised up to the height of the last disastrous floods that had occurred in Bangladesh, was the intensity on people's faces as they stood looking down at the fight in the crater-filled 
landscape. "What were people looking at?" I asked now. "Who knows? Perhaps at how they look when they are fighting?" Khala retorted. "It's reassuring that dogs of our area can band to ward off invading dogs. But they didn't get their fight this morning. So be careful." I was alerted to the importance of both watching dogs and watching out for them.

We cut through the dark courtyards of households filled with their slumbering occupants. We were attending a program at a time when everyone was asleep, although it was no later than 9 p.m. We continued for another ten minutes till we turned yet another dark corner and came upon what might be called a sumptuous sight for these parts: a colorful tent covered the dirt courtyard. Hay was strewn on the floor covered over by gunnysacks. A large number of men were gathered on the sacks. Electric tube lights, several to a grounding rod, were interspersed throughout the space. Although we were there to listen to religious lectures from the bearded and white-clothed men sitting at the front of the gathering, something about the lights seemed unseemly. The few women also gathered there to listen must have felt the same way as they huddled in the shadow of a mud house.

I joined the women and struggled to listen to the voices crackling over the scratchy mike extolling the virtues of prayer as I felt the cold from the ground creep up my legs and possess my body. Then the local maulvi or religious leader, Abdullah Munshi, started speaking. As if aware of the numb that had set in amongst the audience and wishing to stir things up, the preacher launched into a fiery speech about the End Times. "Dajjal (the Islamic anti-Christ), will come as a dead body returned to life. Many will follow him!" he shouted. "We will too," he said to those listening and now shaking their heads more vigorously. "But we will not be humans. We will be dogs." Uncannily, at the moment that he shouted these words, the dogs in the village started barking loudly. In my numbed brain, the frightening intensity of Dajjal combined with images of the snapping, snarling, salivating dogs I had seen earlier in the dogfight. But I was mostly taken aback by the reference to human rebirth.

In Muslim eschatology, humans are resurrected after death only in the event of the Day of Judgment, when they must appear before God to have their good acts and sins weighed against each other to determine the judgment specific to each. In other words, there is no notion of salvation for all humans but only of individual salvation or damnation based on a life's worth of deeds. This is the point that finally won humans the right to subjugate animals within the Ikhwan's fable discussed above. In the fable, humans offer the following as their last-ditch effort to assert their superiority over the other animals: "The promises of our Sovereign to us [is] that we of all the animals will be resurrected and raised up, brought out of our graves and dealt our reckoning on the Day of Judgment" (Ikhwan al-Safa 1978: 200). To this the spokesman of birds replies,

Yes, it is as you say, $\mathrm{O}$ human, but state also the balance of the promise, $\mathrm{O}$ humans, the torment of the grave, the interrogation by Nakir and Munkar, the terrors of the Day of Resurrection, the rigor of the accounting, the threat of entry into the flames and chastisement in Hell and the burning fires of Gehenna, the searing and the blazing, the scorching and the seething of the Abyss, the close shirts of pitch, the drinking of putrescence and purulence, the eating of the Tree of Zaqqum, the nearness of the 
Master of Wrath, Gatekeeper of the Fire, propinquity to the demons, the hordes of Satan all together-all that is stated in the Qur'an. ... All this applies to you and not to us. (ibid.)

With this acknowledgment of the possibility of divine punishment, human were finally granted superiority over other animals, but less on the basis of any intrinsic merit of theirs and more because the animals realized that they may pass away without any fear, whereas the physical end augured only the beginning of human fears. As humans have been granted eternal lives, they may suffer eternally for their cruelty to animals and the animals may have their revenge yet.

In the chars, Abdullah Munshi, the religious leader, who was both a farmer attentive to the land breaking beneath his fields and an octogenarian mindful of life's finitude, focused his sermons not on the Day of Judgment but on the End Times before that day. Even so, he did not cast his sermon quite within the parameters of Muslim eschatology, suggesting a chaura inflection to the usual narratives. For instance, there is no possibility of return prior to the day, much less in the form of another animal in the textual tradition (Smith 1980; Stowasser 2004). And yet in his sermon the humans returned as dogs. The coupling of humans to dogs right away indicated both a return to life and degeneration into a lower form of life, given the low status of dogs in the chars. At the same time, Abdullah Munshi exercised a polysemy of imagery and words in that humans becoming dogs indicated a fall into baseness and an enforced participation in an ordained drama of epic proportions. Humans would return to extend their support to the monstrous Dajjal because their traitorous appetites drew them to it. Note that following one's appetite is not the same as following one's fitra or nature, since in following one's appetite a human forgets his or her nature (Griffel 2007). Humans would also return because they had to undertake their allotted part in the battle that would end with the victory of the Mahdi or the Chosen One and his peaceful reign till the Day of Judgment. In other words, they would be compelled to return as if it were a cosmic debt they owed the world. And in the family of regional folk sayings relating to dogs, the most persistent one is the return of the human as dog if one has died bearing a debt. So greed and debt would ensure humans returning to support the anti-Christ.

The unusualness of the return of humans as dogs within a largely Muslim context that does not normatively subscribe to the idea of rebirth points to the fact that the chars are not homogeneously Muslim spaces. The idiom of rebirth suggests a historical memory of living with Hindus, who were present in large numbers as recently as the early 1970s (van Schendel 2009), or an even deeper historical and structural association of Muslim thought with Vaisnavite Hinduism and Shahajiya Buddhism (Roy 1984). Insofar as the return of humans as dogs hints of rebirth in adjoining traditions, it is noteworthy, as Gananath Obeyesekere writes in his magisterial study of the topic in Buddhism and Hinduism, among other traditions, that rebirth into another species intimates a blurring of boundaries, producing the occasion for cross-species sentience (2002: 346). Goodman (1978), whom I spoke of above with respect to his translation of and introduction to the fable, writes that although the Ikhwan fabulists maintained a strict immutability of species, they granted animals the potential to be subjects in their own right, necessitating that humans acknowledge the possibility of a perspective from another species. In other words, 
Abdullah Munshi's words may be taken to castigate humans for what they are and might yet become, but also to ventriloquize dogs. Listening to the sermon again with Obeyesekere and Goodman in mind, one can understand it as both asserting the degeneration of humans into dogs and the capacity of dogs to feel for humans expressed in their returning as humans on account of human sins and debts.

The night after the Islami shobha, visiting musicians and musicians of the village gathered in one of the office rooms in the NGO compound using my visit as an excuse to sing for one another. While waiting for tea, for others to join them, or for yet another Islami shobha to end its incessant broadcast over the loudspeaker, they kept breaking into song, their knuckles and palms beating out rhythms on the table or on an empty plastic petrol container. They did not wish to sit on chairs, for then the event would not congeal. Instead we sat on the floor. And the music began. The songs, sung full-throatedly and joyfully, were nonetheless ones of the pain of separation and the desire for union with one's beloved. ${ }^{3}$ When I remarked upon this disjuncture between joyful affect and painful yearning, Shontesh, a local big man with blood-shot eyes, a singer of some repute with an intense way about him, explained the quest for union in the following manner:

Say, one has to go from here to Dhaka [the capital of Bangladesh]. One needs Tk. 2000 to get there. One works and earns money. It is not the full amount but it gets the person a certain distance. He dies mid-route. He is reborn as a dog. He must complete the trip so he does what he can to gather a few takas. That gets him a little further. And each version of himself, he must strive to earn the money to get him to his destination.

In the previous instance of the fiery sermon, humans returned as dogs to signal their aliveness and treachery. Yet, as I suggested, the return of dogs as humans turned into dogs nonetheless hinted at their shared sentience and the likelihood of dogs feeling for humans to return as them, to repay cosmic debts. In Shontesh's story, dogs too returned as humans turned into dogs, but did so more in a gesture

3. Unlike other parts of Bangladesh, each with its own distinct musical tradition, the chars in Shirajgonj do not evince any distinct musical styles that I was able to discern. Here anything goes as people bring back bits and pieces of songs from the many places they have lived prior to returning to the char and listen to an even more diverse range of music over their cell phones. I have heard Baul music or Lalon geeti, songs associated with the mystical figure of Lalon Shah, which originates in Khustia, a district nearby to Shirajgonj. Also popular are Pala Gaan, disputations sung in musical competition, originating in Manikganj; Bhatiali is the most naturalistic of song types, associated with downriver scenes such as in Aricha or Mymensingh. Jarigan, or songs that put in narrative the events commemorated in the Islamic month of Muharram, were also very popular. Shontesh, my guide for this evening, was particularly well versed in this last style of song and sometimes earned money by singing in a traveling troupe assembled for the month of Muharram. See Zakariya (2011) for a succinct introduction to the assembly of musical and performance traditions in Bangladesh. On this evening I wasn't yet versed in the different types of music to be able to tell the songs apart; however, I was later told that we mostly heard Bhatiali songs interspersed with a few Lalon geeti, so my attention was directed more to the physical surround than to the inner workings of the body or to religious consciousness. 
of compassion than in the sermon, insofar as the dog returned not out of the pull of coconspiracy or indebtedness but to complete the human's quest for reunion with a beloved. There was a certain joy in knowing that one's journeying would be honored and continued by one's future animal self. Thus, out of the pathos of the inability of humans to sustain cross-species companionship, the dregs of the mangy existence of dogs, and the visceral dislike in which the chauras held the dogs emerges what could be best described as a mutual-fatedness of humans and dogs to each other, the fact of being together at each stage of life. ${ }^{4}$

\section{Materialist metaphysics in the conjunctions of dogs and humans}

The thought of Creation led us to delineate the relationship of humans and dogs within the Muslim textual tradition and the char. It also incorporated the thought of the end/End Times in Muslim eschatology within its movement. If we mull on the specific elements of the end/End Time that have been folded in, we see a charbased variation on the usual lines of narrative. While humans can expect to face the curse of the grave after their demise, they may also be transmuted into another form and returned to life before Judgment Day. Having sketched the possible historical influences enabling such thinking in this region, in this section I consider how such thinking situates dogs and humans in further relations beyond that of mutual fated-ness. Most significantly, we are led to imagine dogs and humans coexisting as competing possibilities within unformed matter. While this thought is derived from the religious sermon and musical event I examined above, it also emerges from everyday life in the chars, from within thinking about the life and death of dogs in relation to those of other animals, and from within voiced concerns about the dwindling quality of life and diminished humanity within the riparian context. It is as if the riparian context makes insistent the focus on matter within Creation narratives through smells, rotting bodies, eroding land, and soil composition (with "soil" being earth in the scientific register and "land" in the legal).

While stories of sushus (dolphins) and kumirs (crocodiles) enter childhood recollections of the few weathered old people in the village, none had been sighted in the last ten years. They were possibly extinct or had been driven away from these parts, largely by the state's damming and bridge-building activities. Their disappearance seemed not to give the chauras a moment's pause. The one time I saw a

4. In his essay on eco-theology, Latour quotes Jakob von Uexkull (1992) to ask that we consider creatures in their own being, that is, taking the risk to reproduce and create their own umwelts. I suggest that species self-perpetuation not be restricted to biological reproduction alone, with becoming, transfiguration, rebirth, symbolic dispersal and resynthesis as further potential modes. The later have been too easily dismissed for entailing the violence of symbolic thought, and this has been a consistent critique of Claude Lévi-Strauss that he considers animals good to think with rather than live with (see Haraway 2007), but I believe that this reproduces an unhelpful divide between idealism and empiricism. I would suggest that we have not yet come to terms with how thinking is not internal to humans and may be engaged by nonhuman others in ways that surprise and extend the capacities of such thinking. 
garden-variety snake, it was promptly killed by my companion, to the screams of horrified delight by the children looking on. When I asked why it had been killed, as it seemed harmless enough, I was told that it is sunnat to kill snakes: that is, a way of life prescribed as normative to Islam based on the teachings and practices of the Prophet. The snake representing his kind at the court of the King of the Jinns had said as much, saying that humans killed snakes based owing to the perception that the snake was intrinsically evil. No such explanation was proffered by the chauras for the catching, careless handling, and subsequent killing of the baby owls born of the tremendous white owl that had moved in to live in the rafters of the building housing my room, the arrival of which had put an end to the swishing of bats and scurrying of mice that had previously disturbed my nights. However, if the owl were to represent itself as it did in the court of the King of Jinns, it might say this: "To them [humans] the very sight of me is ominous. They hate me gratuitously, although I have done them no wrong and caused them no harm" (Ikhwan al-Safa 1978: 102). Meanwhile, other birds, such as pigeons and kites, mice, civet cats, giant salamanders, and foxes, none easily caught, regularly raided the villagers' food sources. Though they were not baited, they were disposed of if caught in the act of theft. None of these deaths caused the chauras any qualms.

The death of farm animals, however, caused the chauras concern, although their response depended largely on the circumstances of the death. Cows, goats, sheep, chickens, and ducks were the animals that were most visible in the chars. They appeared to be as busy as the humans earning their rights to the food provided to them in the form of straw, chaff, and screenings of rice, wheat, and lentils. A large percentage of them were to be sold as food or as objects of ritual sacrifice during the Qurbani Eid as the chauras could ill afford to eat or sacrifice the animals they raised. However, a particularly hard-working farm animal such as a cow or a goat was sometimes given the gift of death in the form of being given to God in sacrifice during Eid in appreciation of its hard work and to release it from its hardship. On one such occasion, Borkot, my young friend, said that he cried as he ate the tough meat of the goat that he had loved and his family had given in sacrifice, but his mother scuffed him on the head, saying that he should rejoice as the goat was freed from the burden of making babies and could now meet its maker. If any farm animal were lost through illness, theft, or accident, this loss was rued, even bemoaned, but one was not particularly vexed by it. There was the occasional charge of witchcraft or evil eye as the cause of an animal's death, but whenever there were more than the usual number of deaths, chauras looked to contamination or epidemics as possible explanations. For instance, a cow plague struck the village during one of my visits. Cows died in scores. Their bodies were simply thrown out, as it was too hard to drag them to the river's edge to dispose of them. This was the wintertime, during which the watery passageways running through the island were long dried and had turned to sand. The corpses were eaten by the stray dogs, which grew fat and salubrious with the sudden bonanza of meat, as did the dog that once had lived on my compound. These deaths were chalked up to anthrax, as was being reported in the Bangla newspapers.

Within this milieu of the seemingly blithe disposal of animals, the forceful suggestion that the dog and her litter in the compound might not be easily killed was what had initially given me pause. Just as my one effort to deal with a dog caused 
the pushback against the killing of God's creations, it was the actual, large-scale killing of dogs that brought about the most visceral response from the chauras to the death of dogs. Just before one of my visits, scores of dogs were stunned by bashing them on their heads with rods, killed by lethal injection, and thrown into the river. Villagers described the act as undertaken by white-coated public health officials brought to the island by parties unknown, presumably to deal a blow to the growing dog population in the area. I later learnt that there existed a public health infrastructure to euthanize or inoculate stray dogs. But it was not self-authorizing, being mobilized by people who wished to rid their localities of the growing menace of stray dogs. Its presence in what is usually termed as "a remote char" indicated the fitful hand of the biopolitical state.

The identities of those who had called in the public health officials were secret. No one knew who had done it. I approached one person who had been bitten by the very dog who had hounded me, counting on a shared antipathy to learn who had engineered the mass killing of the dogs and why. He was cagey, but what he had to say was interesting. He said, "Whoever did it had to do it in secret (goponey) as they don't know what the 'public' [said in English] might do." Dogs and their deaths introduced something unknown into the social.

The public health incursion was both an unsettling and unsettled event, borne out by the fact that although cow carcasses were soon everywhere in evidence and not particularly remarked upon, dog carcasses that had been thrown into the shallow beds of the river were felt to give off an unbelievable stench. People related how they had to avert their eyes and cover their noses as they went past this sight in a way I did not see them do walking past the heaps of rotting cows after the plague. I take my cue of treating smell as indicating an unsettled situation from James Siegel (1983). He writes how the inadvertent stench of dead bodies disrupts the composed mental image of the ideal corpse within Javanese funereal practices. He suggests that odors introduce terror or the terror of the uncontained within the social.

In some ways, I have already been anticipating the terror that the death of a dog or many dogs might provoke. It is the unrestrained thought of one's own death and subsequent decay with the possibility of being formed again as a dog. However, the terror isn't quite as straightforward as this, given the variegated nature of chaura relations to dogs. Kukur, the Bangla word for dog in wide use, has the dictionary meaning of aliveness or presence. Dogs' constancy of presence and prescience of future events were always commented on by the chauras, who related that they sometimes moved to inhabit a char if they saw dogs had come to live there, treating the dogs as harbingers of human settlement. But it was their quality of aliveness, of being more or less useless other than the occasional and fitful protection of households that made them serve as the singular sign of life, a trace of God's surplus creativity. It made dogs the object of some fascination, even voyeurism, for the chauras. Thus human death was a double-edged prospect as kukur hoye jonmayo, a common curse in these parts, was a consignment to be born as dog but also to be born as a sign of life.

The materiality of Creation narratives was distinctly revivified by the riparian context. "If the earth (mati) breaks so much, how do we to stay manush (human)?" asked an old weathered woman of me. New to chaura modes of expressivity, I initially thought the woman was referring to her inability to educate herself or her children to become manush, in its standard meaning of being educated into a cultured 
person. I asked the woman if she had received any education or tried to provide any to her children. She looked at me pityingly as if to suggest that my imagination of what constituted a human was impoverished. She explained patiently that she had come of age in a different era when such training as one receives in schools could no more humanize one than going to the mosque could make one a Muslim. I realized that the relationship of earth to human that she was referring to needed a different understanding.

In the riparian context, land forms and breaks with regular irregularity. The chars that form exist for different periods of time until they are slowly chipped away by the river's many branches or break precipitously during a flood. The chauras move from char to char as erosion consumes the places they have made home. However, since the Jamuna River is shifting its course westward, new people are affected all the time. The river inducts these new affectees into how to live this way, with families learning over time to live mobile lives but also increasingly getting impoverished, unable to recuperate their losses and regain their prior standing with each displacement. So there is a manner in which life proceeds, and instead of feeling in step with it one begins to feel out of sync, watching it pass one by. One can certainly hear the woman give voice to this sense of being out of step with life. If the earth keeps breaking and she keeps stumbling, how is she is to keep pace with the rest of humanity?

But this being an agrarian context in which most chauras farm land as and when it comes up, moving between being farmers of their own land when chars emerge in the location of their original villages, and day laborers on the land of others, the elderly woman can also be heard to give voice to the Creation narrative elaborating the creation of Adam, with Adam as the first manush or human. The Qur'anic verse on the creation of Adam says: "He it is Who created you from clay, and then decreed a stated term [for you]." It is likely the image of a hand shaping a thing out of clay and then breathing life into it that informs the popular imagination on the emergence of humans. Chauras view themselves as Adamites, descendants of the Prophet Adam, through the close association of their livelihood as farmers with the Muslim Bangladeshi perspective of Adam as being created out of clay and working upon the soil (Thorp 1978). In her work on rural cosmology in Turkey, Carol Delaney (1991) further reminds us that the story of Adam is tied up both with the conception of the first human and with conception as such. Reproduction is as central to the story of Creation as Adam's own creation, as Adam and Eve had to populate earth once they were consigned to it. Seen through the prism of Creation, the elderly woman's words may be heard to express something a little different than a failure to keep step with humanity. While Adam's coming to earth was divinely ordained and it came to pass, chauras must similarly come to the chars and populate them, and risk not being able to do so. Their repetition of the arrival of Adam and Eve and flirtation with the failure to arrive draws our attention to their fear that they may not ever come to bear life, to reproduce humans.

There is yet a third way to receive these words spoken by the woman, one provided by the cosmology of modern science. Such a line of analysis is proffered by scholars concerned to secure the scientific basis of the Qur'an, who undertook a research program between 1985 and 1990 under the auspices of the Islamic Foundation in Bangladesh. Their research findings, gathered in Scientific indications in the Holy Qur'an (Islamic Foundation Bangladesh 2004), parse out the possible 
relationship between clay and the origin of life by taking seriously the notion that clay acts as a catalyst for producing proteins and DNA. ${ }^{5}$ They write,

The clay lattice can store energy in the form of electrons and then can release it when subjected to stress caused perhaps from the wetting and drying cycles when the tides rise and recede. The released energy is then available to drive chemical reaction. Thus according to the NASA scientists clays have the unique property of storing energy and catalyzing reactions that join the building blocks into incipient strands of proteins and DNA. (Islamic Foundation Bangladesh 2004: 151)

To explicate this further so that we can better understand the insistent entanglements of physicality with the metaphysical, in Bangladesh the soil (which is earth rendered in the scientific register) is predominantly of three different types: clay, sand, and loam. Clay has the smallest size of particles and sand has the largest. The mixture of the two produces loam. While loam is largely a combination of the two in equal parts, there can be clayey loam with a higher percentage of clay and sandy loam with a higher percentage of sand. This percentage description yields the texture of soil, while the arrangement of the soil particles yields the structure. The micelle structure of soil particles is considered to yield the most arable land. The alluvial sediments that come in the waters of the Jamuna River either become deposited as silt across floodplains or fall in the river to become chars.

Silt, a fourth kind of soil, is distinguished by the high preponderance of stone and minerals in it. In between clay and sand in the size of its particles, it is valuable for enriching standing soil. Yet it is not easy to cultivate. Once it undergoes a process by which alluvium is turned into soil with a distinct texture and structure, such as clay with a micelle structure, then it becomes more conducive to plantation. However, such flood-deposited soil is also greatly prone to acidification and calcification through the leaching of the soil and crack formation, making it vulnerable to erosion by river waters. Consequently, as is frequently pointed out to me by chauras, the islands of the Jamuna arise out of the water, become available for inhabitation within a particular period, with only specific parts available for plantation within a longer stretch of time, and as quickly vulnerable to erosion and breakage (see also Baqee 1998). In other words, it is the arrival of clay that ensures the conditions of possibility for life itself and the achievement of collective life.

If clay is the trace of life, and the earth of the char breaks so often that the time of the arrival of clay is not assured, then alongside an anxiety about being out of step with humanity, and the inability to perpetuate human life, the old woman may be heard to express concern that life has not come to pass within the chars, that one is not alive as yet. Just as in the curse "Be born as a dog," the words "If the earth breaks so much, how do we stay human?" draw our attention insistently to the materialist metaphysics of Creation in the chars.

5. Although these scholars locate themselves within the field of Islam and science, which is concerned with universal achievements within Muslim history, their attention is nonetheless inflected by the concreteness of the world they inhabit. Thus, instead of the fires of hell that inform the wider eschatological imagination, the forces of creation and destruction in the context of deltaic Bangladesh appear to be movements of soil. 


\section{Climate change denialism reconsidered}

One evening in the market, I watched Kalu, the black bear of a dog that Shontesh kept, walk up to his seated master and nuzzle his face. Men fell back in disgust around him. Shohidul, my research assistant, who explains everything, even misinformation, with the confidence of the NGO official that he is, said to him, "Shontesh bhai, you should not let a dog lick you. They are very dirty and will pass their germs to you." Shontesh shrugged. "This dog loves me. I love it. It lives with me. It is as close as any of my children to me. I can't refuse its affection."

I fell into conversation with Shontesh, asking him how he had gotten his dog and what they did together. I became fanciful in my questioning because I asked if he thought his dog would be with him on Judgment Day. I was thinking about dogs in Hindu mythology that accompany humans to Heaven or Hell. At my question, Shontesh sat up in surprise and said, "He can't. There is no Judgment Day for him. There is only Judgment Day for humans because we have been given a conscience (bebaik)." I asked why that was, and, as expected, he said it was because humans were made superior to other creatures and only they were capable of being judged by their Creator in the hereafter.

Thus, within the span of an hour, I went from witnessing cross-species fraternity to the assertion of superiority over all animals. Shontesh was, after all, the musician who sang about the pain of separation from one's beloved and imagined that a human may be reborn in dog form for reconciliation with his or her object of desire. But he was also among those who pulled Poresh out to speak about climate change for entertainment. I finally pressed him as to why he disbelieved in climate change, given that he didn't disbelieve the daily reports he got about possible rain or flood warnings from the government over his cell phone. His spoke in two voices, one pragmatic and one theological, but I suspect that they together help us understand yet another aspect of Creation narratives, that of the force of the belief in the divine privileging of humans and the human right to transcend the ordinary, to aspire to God's position in mind and in action. Shontesh said that the West, which was to blame for creating a mess of the global climate, or so he had heard (Khan 2014), was not to be trusted on any offers of help it gave so belatedly. For instance, he said, pointing to the lush growth of eucalyptus trees at the edge of the market, that they rapidly grow tall in the chars, making them readily available for the wood desperately needed in these parts. A dictate had come from the West through the NGOs not to grow these trees as they drew too much water from the ground, quickly drying it up. He didn't believe this explanation. It was poisonous knowledge to keep the poor down. But he also felt that for the West to even say such a thing was to attempt to delimit God's Creation, which was vast, unfathomable, and unfolding. Who was to say that more water doesn't come into the ground as the trees draw their moisture from it? After all, he pondered, this is an island with water all around it, through it, and even under it for all we know, because chars are such incongruous formations. Even if the trees pulled every drop of water from the ground and it eroded as a result of it, God could make the dispersed soil particles gather together again and could return the char, as he had already done many times in the past. 
If we return in conclusion to the entwined fates of chauras and dogs, it becomes clear that it is the terrain, or earth, that is the condition of possibility for their mutual-fatedness. It would seem that dogs and chauras are so fated insofar as they belong to this earth, held together by a soil that disintegrates and disperses. But what is left unsaid is that although the earth breaks, it reconstitutes. And the inhabitants of this char find themselves here again and again. Many suspect that they will one day find themselves in a diminished form, or occupying a lesser form of life, or even having the status of the resurrected dead, but they will nonetheless always find themselves here at this place in this moment. This is to my ears a statement of eternal return, an attempted transcendence of the ordinary, shot through with deliberate blindness toward the changing present yet also pregnant with the hope of return with companionate others and hangers-on.

Within this denial of climate change, of its encompassment by Creation that is unfolding, unlimited, and repetitious, there is nonetheless the perception of suffering and its possible intensification. The elderly woman spoke of the repetition of the suffering produced by river erosion, Abdullah Munshi recalled End Times bringing a fearful apocalyptic future into the present, and Shontesh, the musician, evoked the eternal quest for union with a beloved without end. While not focused on a specific horizon, these preoccupations suggest that the narrative of climate change tends to a fast-approaching but still somewhat distant horizon, the future is already experienced as staggered, even foreshortened, with some horizons already upon us. These foreshortened horizons bear witness to the unfolding of climate change through the intensification of existing scenes of suffering, even as climate change is considered further poisonous knowledge from the West.

\section{Acknowledgments}

Research for this article was funded by The American Institute of Bangladesh Studies and The Wenner-Gren Foundation.

\section{References}

Baqee, Abdul. 1998. Peopling in the land of Allah Jaane: Power, peopling and environmentthe case of char-lands of Bangladesh. Dhaka: The University Press Ltd.

Basu, Nogendro Nath. 1997. “About dogs (kukurkey niyeh).” Special issue, “Doglore," Loksamaskriti Gabeshana 10: 131-38.

Delaney, Carol. 1991. The seed and the soil: Gender and cosmology in Turkish Muslim society. Berkeley: University of California Press.

Edwards, Paul N. 2010. A vast machine: Computer models, climate data, and the politics of global warming. Cambridge, MA: MIT Press.

Goodman, Lenn. E. 1978. "Introduction." In The case of the animals versus man before the King of the Jinn, Ikhwan al-Safa. Translated by Lenn E. Goodman. Boston: Twayne Publishers. 
Griffel, Frank. 2007. "The harmony of natural law and Shari'a in Islamic theology." In Sharia: Islamic law in the contemporary context, edited by Abbas Amanat and Frank Griffel, 38-61. Palo Alto, CA: Stanford University Press.

Haraway, Donna. 2007. When species meet. Minneapolis: University of Minnesota Press.

Ikhwan al-Safa. 1978. The case of the animals versus man before the King of the Jinn. Translated by Lenn E. Goodman. Boston: Twayne Publishers.

Islamic Foundation Bangladesh. 2004. Scientific indications in the Holy Qur'an. Dhaka: Islamic Foundation Bangladesh.

Khan, Naveeda. 2014. "The death of nature in the era of global warming." In Wording the world: Veena Das and scenes of inheritance, edited by Roma Chatterji, 288-99. New York: Fordham University Press.

Latour, Bruno. 2009. "Will non-humans be saved? An argument in ecotheology." Journal of the Royal Anthropological Institute (N.S.) 15: 459-75.

Lévi-Strauss, Claude. 1961. Tristes tropiques. New York: Criterion Books.

Manzoor, S. Parvez. 2003. "Nature and culture: An Islamic perspective.” In Nature across cultures: Views of nature and the environment in non-Western cultures, 421-32. Dordrecht: Kluwer Academic Publishers.

Morton, Tim. 2010. The ecological thought. Cambridge, MA: Harvard University Press.

Murata, Sachiko, and William Chittick. 1998. The vision of Islam. St Paul, MN: Paragon Publishers.

Nasr, Seyyed Hossein. 1993. An introduction to Islamic cosmological doctrines. Albany: State University of New York Press.

Norgaard, Kari Marie. 2011. Living in denial: Climate change, emotions, and everyday life. Cambridge, MA: MIT Press.

Obeyesekere, Gananath. 2002. Imagining karma: Ethical transformation in Amerindian, Buddhist, and Greek rebirth. Berkeley: University of California Press.

Roff, William R. 1983. "Whence cometh the law? Dog saliva in Kelantan, 1937." Comparative Studies in Society and History 5 (2): 323-38.

Roy, Asim. 1984. The Islamic syncretistic tradition in Bengal. Princeton, NJ: Princeton University Press.

Siegel, James. 1983. “Images and odors in Javanese practices surrounding death.” Indonesia 36: $1-14$.

Smith, Jane I. 1980. "Concourse between the living and the dead in Islamic eschatological literature." History of Religions 19 (3): 224-36.

Stowasser, Barbara Freyer F. 2004. "The end is near: Minor and major signs of the hour in Islamic texts and contexts." In Apocalypse and violence, edited by Abbas Amanat and John J. Collins, 45-67. New Haven, CT: Yale Center for International and Area Studies.

Thorp, John P. 1978. Power among the farmers of Daripalla: A Bangladesh village study. Dhaka: Caritas Bangladesh.

van Schendel, Willem. 2009. A history of Bangladesh. Cambridge: Cambridge University Press. 
von Uexküll, Jakob. 1992. "A stroll through the worlds of animals and men: A picture book of invisible worlds." Semiotica 89: 319-91.

Zakaria, Saymon. 2011. Pronomohi bongomata: Indigenous cultural forms of Bangladesh. Dhaka: Nymphea Publication.

\section{Les chiens, les humains, et ce que la terre peut être: Filaments de pensée écologique musulmane}

Résumé : Le changements climatique est une forme de savoir produit en analysant des données empiriques avec des modèles de simulation globaux. Par contraste avec des études qui montrent comment les individus sont éduqués à percevoir le changement climatique ou à donner leur point de vue sur ce changement dans un idiome indigène, jétudie le scepticisme à légard de ce savoir des fermiers musulmans (chauras) qui vivent dans des terrains sableux qui sérodent et des îles de sable (chars) de la rivière Jamuna au Bangladesh. Ce scepticisme s'apparente au déni que suscite en d'autres endroits le changement climatique. Si nous cessions de nous intéresser à la manière dont les gens s'approprient (ou non) le problème du changement climatique, nous pourrions voir que ce sont dans les gestes plus anodins visant à intégrer des autres répugnants, en l'occurrence des chiens, que l’on peut étudier la réflexion sur la création divine, en tant que réflexion sur la condition de créature. En s'inspirant des réflexions sur la Création tirées des fables, de récits, et du quotidien des chauras, on s'aperçoit que la cosmologie et l'eschatologie musulmanes contiennent les germes d'une pensée écologique, qui se caractérisent par une perspective étonnamment matérialiste sur notre connexion au monde en tant que créatures. Elles contiennent aussi un registre anticipatif quant au changement climatique, à l'œuvre dans la vie des chauras à travers des éléments suggérant l'intensification de la souffrance dans le présent, tout en permettant le scepticisme quant au changement climatique, perçu comme un savoir occidental empoisonné.

Naveeda KHAN is Associate Professor of Anthropology at Johns Hopkins University. She is the editor of Beyond crisis: Re-evaluating Pakistan (2010) and the author of Muslim becoming: Aspiration and skepticism in Pakistan (2012). She is currently working on a book manuscript tentatively titled Romantic climate change and riparian life in Bangladesh, which is based on her fieldwork on accreting and eroding silt islands within the Jamuna River in Bangladesh. Her interest is in exploring the physiognomy of nature from within the riparian form of life.

Naveeda Khan

Department of Anthropology

Johns Hopkins University

404 Macaulay

3400 North Charles Street

Baltimore, MD 21218

USA

nkhan5@jhu.edu 